\title{
Co-localisation of insulin-like growth factor II and the proliferation marker MIB1 in hepatocellular carcinoma cells
}

\author{
T Sohda, Y Oka, K Iwata, J Gunn, S Kamimura, H Shijo, M Okumura, K Yun
}

\begin{abstract}
Aim-To assess the effect of insulin-like growth factor II (IGF-II) on proliferation of hepatocellular carcinoma (HCC) cells. Methods-Expression of IGF-II mRNA and protein was detected in 10 archival HCC specimens using in situ hybridisation and immunohistochemistry, respectively. Expression of the Ki-67 antigen, a proliferation marker, was determined immunohistochemically on the same sections.

Results-Increased expression of IGF-II mRNA and protein was detected in five of the $10 \mathrm{HCCs}$ in cells located at the periphery of tumour nests. The pattern of localisation of IGF-II was almost identical with that of Ki-67 antigen.

Conclusions-Most of the Ki-67 antigen positive cells co-expressed IGF-II, suggesting that IGF-II may act as an autocrine or paracrine growth factor, and may play an important role in the development of HCC.

(F Clin Pathol 1997;50:135-137)
\end{abstract}

Keywords: insulin-like growth factor II; transcriptional regulation; autocrine/paracrine growth; Ki-67 antigen; human hepatocellular carcinoma.

First Department of Internal Medicine, School of Medicine, Fukuoka University, Fukuoka, Japan T Sohda

K Iwata

$S$ Kamimura

H Shijo

M Okumura

Department of Gastroenterology, Fukuoka University Chikushi Hospital Y Oka

Department of Pathology, University of Otago Medical School, Dunedin, New Zealand

J Gunn

K Yun

Correspondence to: Dr T Sohda, First Department of Internal Medicine, School of Medicine, Fukuoka University, 7-45-1 Nanakuma, Jonan-ku, Fukuoka 814- 80 Japan.

Insulin-like growth factor II (IGF-II) is believed to play an important role in fetal growth and development. ${ }^{1}$ Recently, several investigators have reported increased expression of the IGF-II gene in a variety of human tumours. ${ }^{23}$ It has also been reported that IGF-II is expressed in human hepatocellular carcinoma (HCC) with a high frequency, suggesting that IGF-II may be involved in hepatocarcinogenesis. ${ }^{4-7}$ Insulin-like growth factors have been implicated in the deregulation of growth control in hepatocytes during malignant transformation via an autocrine mechanism. ${ }^{8} 9$ We have designed a study using in situ hybridisation and immunohistochemical techniques to assess the effect of IGF-II on proliferation of tumour cells in HCC. We have compared expression of IGF-II mRNA/IGF-II protein with proliferative activity at the cellular level. Proliferative activity was assessed by using the MIB1 antibody which detects the $\mathrm{Ki}-67$ antigen.

\section{Methods}

Ten archival HCCs complicating liver cirrhosis were studied. All 10 patients had died of their disease. Seven tumours were associated with hepatitis $\mathrm{C}$ virus (HCV) and three with hepatitis $B$ virus (HBV) infection. All liver samples had been fixed in $10 \%$ buffered formalin and embedded in paraffin wax. Serial, $5 \mu \mathrm{m}$ thick, sections were cut and mounted on $2 \%$ 3-aminopropyltriethoxysilane coated slides. Sections from all tumours were stained with haematoxylin and eosin for histopathological examination.

IN SITU HYBRIDISATION

The in situ IGF-II mRNA hybridisation protocols used were as described by Yun et al. ${ }^{3}$ Briefly, the hybridisation solution contained $50 \%$ formamide, $2 \times \mathrm{SSC}, 0.15 \mathrm{M} \mathrm{NaCl}$, $0.2 \mathrm{mg} / \mathrm{ml}$ Escherichia coli tRNA, $1 \mathrm{mg} / \mathrm{ml}$ degraded herring sperm DNA, $0.1 \mathrm{mg} / \mathrm{ml}$ bovine serum albumin, $10 \%$ polyethylene glycol, $0.2 \mathrm{M}$ dithiothreitol, and $\left[{ }^{35} \mathrm{~S}\right] \mathrm{CTP}$ labelled antisense or sense RNA probe $(40000 \mathrm{cpm} / \mu \mathrm{l})$ and was kept at $50^{\circ} \mathrm{C}$ overnight. The slides were washed prior to RNase treatment. For autoradiography, slides were dipped in nuclear emulsion and exposed for two weeks at $4^{\circ} \mathrm{C}$. After development, the slides were counterstained with haematoxylin and eosin.

\section{IMMUNOHISTOCHEMISTRY}

For IGF-II, dewaxed sections were rehydrated through an alcohol series and overlaid with a $10 \%$ non-fat milk solution to block nonspecific protein binding. Mouse monoclonal antibody directed against rat IGF-II (Amano Pharmaceutical Co, Osaka, Japan) was used at a final dilution of 1 in 400 and incubated with the sections overnight at $4^{\circ} \mathrm{C}$. Sections were incubated with biotinylated horse anti-mouse IgG (Vector Laboratories, Burlingame, California, USA) and alkaline phosphatase avidin D (Vector Laboratories). Sections were then treated with biotinylated goat anti-avidin D (Vector Laboratories) and again with alkaline phosphatase avidin D. Nitroblue tetrazolium with 5-bromo-4-chloro-3-indolylphosphate (NBT/BCIP: BluGENE kit, BRL, Gaithersburg, Maryland, USA) was used as the immunoreactive alkaline phophatase substrate.

Cellular proliferation was assessed in serial sections using the MIB1 antibody (Immunotech S.A., Marseille, France) directed against the $\mathrm{Ki}-67$ antigen by means of the streptavidin-biotin complex method. Initially, dewaxed sections were autoclaved for $10 \mathrm{~min}$ utes at $120^{\circ} \mathrm{C}$ in a $0.01 \mathrm{M}$ citrate buffer $(\mathrm{pH}$ 6.0) to improve antigen retrieval. MIB1 was used at a final dilution of 1 in 100. Naphthol- 

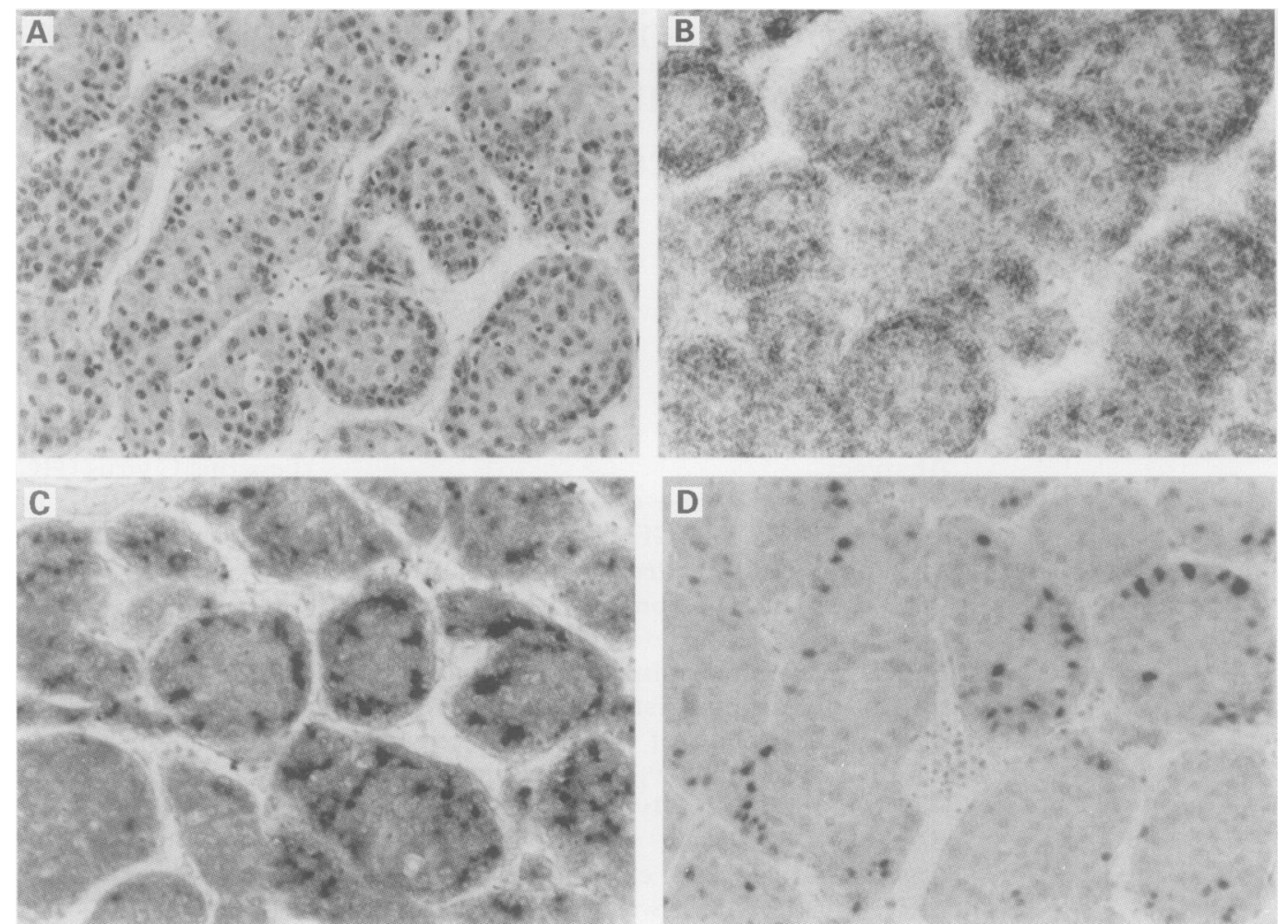

Figure 1 (A) Less well differentiated tumour cells at periphery of the HCC nests are small and have ill-defined cytoplasm and hyperchromatic nuclei. The central area of the tumour nests consists of well differentiated cells, reminiscent of adult hepatocytes, which show no detectable level of transcripts. (B) Increased levels of IGF-II expression were detected using in situ hybridisation at the periphery of the tumour nests. (C) IGF-II protein can be seen as dense globular or granular deposits in the cytoplasm. (D) Expression of the Ki-67 antigen in the nuclei of less well differentiated tumour cells. (Original magnification $\times 100$.)

AS-BI-phosphate (Sigma, St Louis, Missouri, USA) was used as a substrate and new fuchsin (Merck, Darmstadt, Germany) as a coupler.

Sections were double immunostained as described by Tashiro et al. ${ }^{10}$ After MIB1 immunostaining, the slides were washed in three changes of $0.1 \mathrm{M}$ glycine- $\mathrm{HCl}(\mathrm{pH} 2.2)$ for 30 minutes to remove the previous antibodies, and subsequently stained with an antibody directed against IGF-II as described earlier. Cells reacting with the MIB1 antibody stained red, whereas those reacting with the antibody directed against IGF-II stained dark blue.

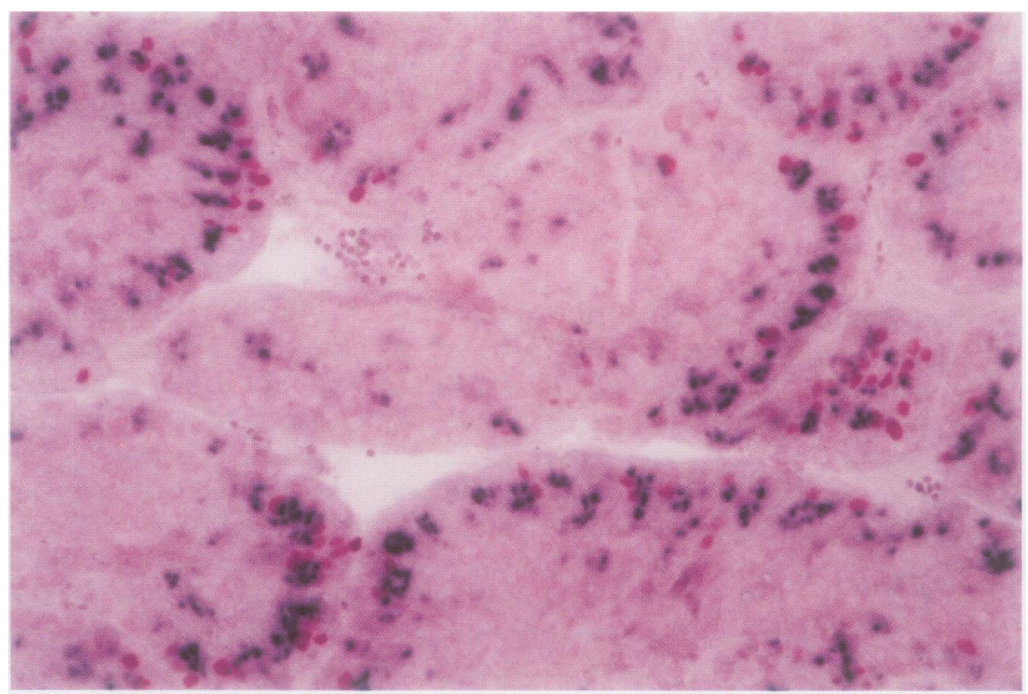

Figure 2 Double immunostaining with MIB1 and antibody directed against IGF-II showed that most of the Ki-67 antigen positive cells (red) also express IGF-II (dark blue) (original magnification $\times 200$ ).

\section{Results}

Expression of IGF-II was increased in five of the 10 HCCs examined by in situ hybridisation in comparison with the surrounding cirrhotic liver. Four of these five HCCs were associated with $\mathrm{HCV}$ infection and the remaining one with HBV infection. IGF-II mRNA was detected specifically in areas consisting of less well differentiated tumour cells which were present at the periphery of the HCC tumour nests (figs $1 \mathrm{~A}$ and $1 \mathrm{~B}$ ). IGF-II protein expression was also detected in these five HCC specimens only and was also localised at the periphery of the tumour nests (fig $1 \mathrm{C}$ ).

$\mathrm{Ki}-67$ antigen was immunolocalised to nuclei of less well differentiated tumour cells in all 10 HCCs (fig 1D). The numbers of Ki-67 antigen positive cells in the five HCCs expressing IGF-II mRNA/IGF-II protein and in the other five cases were not significantly different. Very occasional positive cells were also seen in the surrounding cirrhotic liver. The pattern of expression of IGF-II mRNA and protein and the $\mathrm{Ki}-67$ antigen was very similar-expression was localised to the periphery of the tumour nests. Moreover, double immunostaining with antibodies directed against IGF-II and $\mathrm{Ki}-67$ showed that most of $\mathrm{Ki}-67$ antigen positive cells also expressed IGF-II (fig 2). These results strongly suggest that, in HCCs expressing IGF-II $\mathrm{mRNA}$ and protein, synthesis of IGF-II is (1) primarily regulated at the transcriptional level and (2) correlated with the proliferative activity of tumour cells. 


\section{Discussion}

We have compared the localisation of IGF-II producing cells with that of $\mathrm{Ki}-67$ antigen positive cells. Expression of the $\mathrm{Ki}-67$ antigen is increased in HCC. ${ }^{11}$ Five of 10 HCCs in this study expressed IGF-II and its pattern of localisation was almost identical with that of $\mathrm{Ki}-67$ antigen, as demonstrated by double immunostaining on the same tissue sections. This suggests that IGF-II may be involved in the regulation of cellular proliferation in HCC by an autocrine or paracrine mechanism. This finding is consistent with a study on IGF-II transgenic mice which demonstrated that persistently maintained, high level expression of IGF-II was implicated in the development of HCC and other tumours. ${ }^{12}$

Su $e t a l^{6}$ suggested that a product derived from HBV may activate the IGF-II gene promoter. In addition, recent studies have also detected high levels of IGF-II transcripts in $\mathrm{HCV}$ positive HCCs. ${ }^{13}{ }^{14}$ In our study, IGF-II was expressed in both $\mathrm{HCV}$ positive and HBV positive HCCs, suggesting that these viruses may share common mechanisms by which they activate the IGF-II transcription factor.

Our data demonstrate that the increased synthesis of IGF-II mRNA and protein is associated with increased cellular proliferation in HCC. Further studies on the role of IGF-II in the proliferation of tumour cells may elucidate its mechanism of action in malignant transformation. However, as five of the $10 \mathrm{Ki}-67$ positive HCCs did not express IGF-II, regulating factors other than IGF-II may be present.
1 Moses AC, Nissley SP, Short PA, Rechler MM, White RM, Knight $A B$, et al. Increased levels of multiplication stimulation activity, an insulin-like growth factor, in fetal rat serum. Proc Natl Acad Sci USA 1980;77:3649-53.

2 Yun K. A new marker for rhabdomyosarcoma: Insulin-like growth factor II. Lab Invest 1992;67:653-64.

3 Yun $K$, Fidler AE, Eccles MR, Reeve AE. insulin-like growth factor II and WT1 transcript localization in human fetal kidney and Wilms' tumor. Cancer Res 1993;53:5166fetal

D'Arville CN, Nouri-Aria KT, Johnson P, Williams R Regulation of insulin-like growth factor II gene expression by hepatitis B virus in hepatocellular carcinoma. Hepatology 1991;13:310-5.

5 Lamas E, LeBail B, Housset C, Boucher O, Brechot C. Localization of insulin-like growth factor-II and hepatitis B virus $m R N A$ and proteins in human hepatocellular carcinomas. Lab Invest 1991;64:98-104

6 Su Q, Liu Y-F, Zhang J-F, Zhang S-X, Li D-F, Yang J-J. Expression of insulin-like growth factor II in hepatitis B, cirrhosis and hepatocellular carcinoma: its relationship with hepatitis B virus antigen expression. Hepatology 1994; 19:788-99.

7 D'Errico A, Grigioni WF, Fiorentino M, Baccarini P, Lamas E, De Mitri MS, et al. Expression of insulin-like growth E, De Mitri MS, et al. Expression of insulin-like growth
factor II (IGF-II) in human hepatocellular carcinomas: An factor II (IGF-II) in human hepatocellular carcinomas: A
immunohistochemical study. Pathol Int 1994;44:131-7.

8 Sporn MB, Todaro GJ. Autocrine secretion and malignan transformation of cells. $N$ Engl $\mathcal{F}$ Med 1980;303:878-80.

9 Sporn MB, Robert AB. Autocrine growth factors and cancer. Nature 1985;313:745-7.

10 Tashiro $\mathrm{H}$, Iwasaki $\mathrm{H}$, Kikuchi $\mathrm{M}$, Ogata $\mathrm{K}$, Okazaki $M$ Giant cell tumors of tendon sheath, a single and multiple immunostaining analysis. Pathol Int 1995;45:147-55.

11 Grigioni WF, D'Errico A, Bacci F, Gaudio M, Mazziotti A Gozzetti G, et al. Primary liver neoplasms, evaluation of proliferative index using MoAb Ki67. ₹ Pathol 1989;158: prolife.

12 Rogler CE, Yang D, Rossetti L, Donohoe J, Alt E, Chang $\mathrm{CJ}$, et al. Altered body composition and increased frequency of diverse malignancies in insulin-like growth factor-II transgenic mice. F Biol Chem 1994;269:13779-84

13 Nardone G, Romano M, Calabro A, Pedone PV, de Sio I, Persico M, et al. Activation of fetal promoters of insulin-like growth factor II gene in hepatitis C virus, related chronic hepetitis, cirrhosis, and hepatocellular carcinoma. Hepatol ogy 1996;23:1304-12.

14 Sohda $T$, Kamimura S, Iwata $K$, Shijo $H$, Okumura $M$ Immunohistochemical evidence of insulin-like growth factor II in human small hepatocellular carcinoma with hepatitis $C$ virus infection: Relationship to fatty change in carcinoma cells. $\mathcal{f}$ Gastroenterol Hepatol 1997 (in press). 